\title{
Enzyme complex supplementation in different nutrient levels diets on pigs feces excretion and anaerobic digestion
}

\author{
Urbano dos Santos Ruiz ${ }^{*}$, Maria Cristina Thomaz², Jorge de Lucas Júnior², Leonardo Augusto Fonseca Pascoal ${ }^{3}$, Pedro \\ Henrique Watanabe ${ }^{4}$, Alessandro Borges Amorim ${ }^{5}$, Cristiane de Almeida Neves Xavier ${ }^{6}$, Adriane Andrade Silva ${ }^{7}$
}

'University of São Paulo/ESALQ - Dept. of Animal Science, Av. Pádua Dias, 11 - 13418-900 - Piracicaba, SP - Brazil. ${ }^{2}$ São Paulo State University - Dept. of Animal Science, Via de Acesso Prof. Paulo Donato Castellane, s/n - 14884-900

- Jaboticabal, SP - Brazil.

${ }^{3}$ Federal University of Paraiba - Dept. of Animal Science, Campus III, s/n - 58220-000 - Bananeiras, PB - Brazil.

${ }^{4}$ Federal University of Ceará - Dept. of Animal Science, Av. Mister Hull, s/n - 60020-181 - Fortaleza, CE - Brazil.

${ }^{5}$ Federal University of Mato Grosso/Institute of Agricultural and Technological Sciences, Av. dos Estudantes, 5055 78735-902 - Rondonópolis, MT - Brazil.

${ }^{6}$ Federal University of Mato Grosso do Sul/FAMEZ, Av. Senador Felinto Müller, 2443 - 79070-900 - Campo

Grande, MS - Brazil.

7Federal University of Uberlândia/Institute of Agriculture Sciences, R. Goiás, 2000 - 38500-000 - Monte Carmelo, MG - Brazil.

*Corresponding author <usruiz@usp.br>

Edited by: Gerson Barreto Mourão

Received February 25, 2016

Accepted June 27, 2016
ABSTRACT: This research aimed to evaluate enzyme supplementation in diets with different nutritional levels for pigs in their feces excretion and anaerobic digestion. Fifty four gilts were placed on diets formulated to achieve 100 or 95 or $90 \%$ of a pig's nutrient requirements, with the addition of an enzyme complex containing amylase, $\beta$-glucanase, cellulase, pectinase, xylanase, protease and phytase (diets 100E, 95E and 90E) or without the enzymes (diets 100, 95 and 90 ). The trial was divided into three periods (1, 1-2 and 1-3) based on the animal weight. The enzyme complex reduced $(p<0.05)$ excretions per period and per unit of weight gain (residue coefficients) of organic matter (OM) in Period 1, of N, Ca, $\mathrm{Zn}$ and $\mathrm{Na}$ in Period 1-2, and of $\mathrm{Na}$ excretions and residue coefficients in Period 1-3. Animals fed diet 95E had lower excretions ( $p<0.05$ ) of dry (DM), organic and mineral matters, $\mathrm{N}, \mathrm{Ca}, \mathrm{Fe}, \mathrm{Mn}$ and $\mathrm{Cu}$, and lower residue coefficients $(p<0.05)$ of $\mathrm{DM}, \mathrm{OM}, \mathrm{P}, \mathrm{Fe}, \mathrm{Mn}$ and $\mathrm{Cu}$ compared with the animals fed diet 95, in Period 1-3. Numerically, the enzyme complex improved biogas and methane production potentials in anaerobic digestion of the feces. The use of an enzyme complex in a diet formulated to provide $95 \%$ of the gilts' nutrient requirements reduced fecal excretion and positively affected the anaerobic digestion of feces. These data show that pig nutrition and feeding are important tools for reducing the potential environmental impact of pig production. Keywords: biogas, environmental impact, fecal production, swine

\section{Introduction}

In intensive pig production, the use of techniques to minimize manure production and to recycle this manure is essential to limiting environmental damage. In this context, animal feeding is important because it is directly involved in the production of feces and urine, the main components of manure, and therefore in its treatment process.

Excretion by pigs, as in any other animal, corresponds mainly to the consumed feed fractions which were not digested, absorbed or retained by the animals. Thus, the production of manure and its physicochemical characteristics are related to swine nutrition and feeding. Nutritional strategies that improve nutrient and energy use by animals can reduce their organic and mineral matter excretion per unit of feed consumed (Aarnink and Verstegen, 2007; Dourmad and Jondreville, 2007; Ferket et al., 2002).

In addition, the manure composition influences the processes involved in anaerobic digestion, which is a way to treat and recycle the manure that is based on the microbial degradation of the slurry under controlled conditions. Recent studies have demonstrated that there is a direct relationship between manure quality and the anaerobic digestion process (Miranda et al., 2012; Orrico et al., 2007; Orrico et al., 2010).

An interesting nutritional strategy that can improve diet digestibility and, as a consequence, reduce the potential environmental impact of pig production, is the addition of exogenous enzymes to the animals' diets. This technique aims to complement the synthesis of endogenous enzymes by the animals or to provide enzymes that are not produced by swine, and thereby improve feed utilization (Adeola and Cowieson, 2001).

The aim of the present research was to evaluate the effect of adding dietary enzymes to diets with different nutrient levels for gilts. This effect was evaluated by examining the composition (i.e., dry matter, organic and mineral matter, nitrogen and macro and micro minerals) and excretion of feces by gilts, and by determining how animal excretion was related to weight gain and the anaerobic digestion of feces.

\section{Materials and Methods}

The animal procedures followed the guidelines established by the Brazilian Council of Animal 
Experimentation and were reviewed and approved by the "São Paulo State University" Committee of Ethics and Animal Welfare. The trials were conducted in Jaboticabal, SP, Brazil (21ํ15'16" S; 48 19'19" W, altitude $607 \mathrm{~m}$ ). Fifty-four crossbred gilts (aged 50 days old and with $19.9 \pm 1.7 \mathrm{~kg}$ of body weight) of a commercial line were housed individually in $2.55 \mathrm{~m}^{2}$ pens equipped with nipple drinkers and semi-automated feeders.

The animals were assigned to one of six experimental diets (Table 1) based on corn, soybean meal and wheat middlings and prepared with or without an enzyme complex and with different nutrient levels. The enzyme complex, which was obtained from the fermentation of Aspergillus niger, contained amylase (30 FAU g ${ }^{-1}$ ), $\beta$-glucanase (200 BGU g ${ }^{-1}$ ), cellulase (40
CMCU $g^{-1}$ ), pectinase (4000 AJDU $g^{-1}$ ), xylanase (100 XU $\left.\mathrm{g}^{-1}\right)$, protease $\left(700 \mathrm{HUT}^{-1}\right.$ ) and phytase (300 FTU $\left.\mathrm{g}^{-1}\right)$ and was added to the diets to replace part of the inert component. The diets were formulated to achieve 100,95 or $90 \%$ of the animals' nutrient requirements in terms of metabolizable energy, digestible lysine, methionine and cystine, threonine and tryptophan, calcium and available phosphorus, with the addition of the enzyme complex (diets 100E, 95E and 90E, respectively) or without the enzyme complex (diets 100, 95 and 90, respectively). The analyzed contents of dry, mineral and organic matters, nitrogen and minerals of the diets are presented in Table 2.

The trial was divided into three phases according to the weight of the animals. Phase 1 was initiated when

Table 1 - Ingredients and calculated chemical composition of pigs' diets in Phases 1 (19.90 \pm 1.67 to $31.13 \pm 2.95 \mathrm{~kg}$ of body weight - BW), 2 ( $31.13 \pm 2.95$ to $70.34 \pm 6.36 \mathrm{~kg}$ of BW) and 3 (70.34 \pm 6.36 to $96.49 \pm 8.98 \mathrm{~kg}$ of BW).

\begin{tabular}{|c|c|c|c|c|c|c|c|c|c|}
\hline & \multicolumn{3}{|c|}{ Phase 1} & \multicolumn{3}{|c|}{ Phase 2} & \multicolumn{3}{|c|}{ Phase 3} \\
\hline & $\begin{array}{c}100 \\
100 E\end{array}$ & $\begin{array}{c}95 \\
95 \mathrm{E}\end{array}$ & $\begin{array}{c}90 \\
90 \mathrm{E}\end{array}$ & $\begin{array}{c}100 \\
100 E\end{array}$ & $\begin{array}{c}95 \\
95 \mathrm{E}\end{array}$ & $\begin{array}{c}90 \\
90 \mathrm{E}\end{array}$ & $\begin{array}{c}100 \\
100 E\end{array}$ & $\begin{array}{c}95 \\
95 \mathrm{E}\end{array}$ & $\begin{array}{c}90 \\
90 \mathrm{E}\end{array}$ \\
\hline \multicolumn{10}{|l|}{ Ingredients (\%) } \\
\hline Corn & 54.00 & 55.49 & 55.52 & 52.58 & 55.11 & 54.63 & 53.95 & 55.49 & 55.12 \\
\hline Soybean meal & 20.68 & 21.45 & 21.48 & 18.57 & 18.57 & 18.33 & 15.05 & 15.84 & 15.65 \\
\hline Wheat middling & 15.50 & 16.84 & 16.82 & 19.45 & 20.45 & 21.44 & 22.00 & 23.20 & 23.99 \\
\hline Soybean oil & 5.11 & 1.94 & - & 5.13 & 1.91 & - & 5.07 & 1.93 & - \\
\hline Dicalcium phosphate & 1.90 & 1.71 & 1.57 & 1.49 & 1.31 & 1.22 & 1.26 & 1.07 & 0.98 \\
\hline Limestone & 0.64 & 0.65 & 0.63 & 0.77 & 0.78 & 0.76 & 0.81 & 0.84 & 0.79 \\
\hline Salt & 0.45 & 0.44 & 0.44 & 0.41 & 0.41 & 0.41 & 0.36 & 0.36 & 0.36 \\
\hline Inert* & 0.52 & 0.52 & 2.75 & 0.52 & 0.56 & 2.50 & 0.52 & 0.52 & 2.50 \\
\hline Mineral supplement & $0.05^{1}$ & $0.05^{1}$ & $0.05^{1}$ & $0.05^{3}$ & $0.05^{3}$ & $0.05^{3}$ & $0.04^{5}$ & $0.04^{5}$ & $0.04^{5}$ \\
\hline Vitamin supplement & $0.10^{2}$ & $0.10^{2}$ & $0.10^{2}$ & $0.08^{4}$ & $0.08^{4}$ & $0.08^{4}$ & $0.06^{6}$ & $0.06^{6}$ & $0.06^{6}$ \\
\hline L - Lysine $\mathrm{HCl}, 78$ \% & 0.59 & 0.47 & 0.41 & 0.51 & 0.43 & 0.37 & 0.47 & 0.37 & 0.32 \\
\hline L - Threonine, $98 \%$ & 0.22 & 0.17 & 0.12 & 0.20 & 0.16 & 0.12 & 0.20 & 0.14 & 0.11 \\
\hline DL - Methionine, $99 \%$ & 0.16 & 0.11 & 0.08 & 0.16 & 0.12 & 0.09 & 0.14 & 0.09 & 0.06 \\
\hline L - Tryptophan, $98.5 \%$ & 0.03 & 0.01 & - & 0.03 & 0.01 & - & 0.03 & 0.01 & - \\
\hline Choline chloride, $60 \%$ & 0.03 & 0.03 & 0.03 & 0.03 & 0.03 & 0.03 & 0.02 & 0.02 & 0.02 \\
\hline Antioxidant & 0.02 & 0.02 & - & 0.02 & 0.02 & - & 0.02 & 0.02 & - \\
\hline \multicolumn{10}{|c|}{ Calculated nutrient levels (\% as fed) } \\
\hline Crude protein & 17.03 & 17.53 & 17.42 & 16.49 & 16.71 & 16.60 & 15.37 & 15.90 & 15.77 \\
\hline Digestible lysine & 1.15 & 1.09 & 1.04 & 1.05 & 1.00 & 0.95 & 0.95 & 0.90 & 0.86 \\
\hline Digestible threonine & 0.72 & 0.69 & 0.65 & 0.68 & 0.65 & 0.61 & 0.64 & 0.60 & 0.57 \\
\hline Digestible methionine + cystine & 0.64 & 0.61 & 0.58 & 0.63 & 0.60 & 0.57 & 0.59 & 0.56 & 0.53 \\
\hline Digestible tryptophan & 0.20 & 0.19 & 0.18 & 0.19 & 0.18 & 0.17 & 0.18 & 0.17 & 0.16 \\
\hline Calcium & 0.80 & 0.76 & 0.72 & 0.75 & 0.71 & 0.68 & 0.70 & 0.67 & 0.63 \\
\hline Available phosphorus & 0.40 & 0.38 & 0.36 & 0.35 & 0.33 & 0.32 & 0.32 & 0.30 & 0.29 \\
\hline Total carbohydrates & 57.8 & 60.0 & 60.1 & 58.5 & 61.0 & 61.2 & 59.9 & 62.1 & 62.3 \\
\hline Non-fibrous carbohydrates & 42.3 & 43.7 & 43.7 & 41.9 & 43.7 & 43.6 & 42.6 & 44.0 & 43.9 \\
\hline $\begin{array}{l}\text { Neutral detergent fiber } \\
\text { Metabolizable energy }\left(\mathrm{kcal} \mathrm{kg}^{-1}\right)\end{array}$ & $\begin{array}{l}15.5 \\
3300\end{array}$ & $\begin{array}{l}16.3 \\
3135\end{array}$ & $\begin{array}{l}16.3 \\
2970\end{array}$ & $\begin{array}{l}16.6 \\
3280\end{array}$ & $\begin{array}{l}17.3 \\
3116\end{array}$ & $\begin{array}{l}17.6 \\
2952\end{array}$ & $\begin{array}{l}17.3 \\
3270\end{array}$ & $\begin{array}{l}18.1 \\
3106\end{array}$ & $\begin{array}{l}18.4 \\
2943\end{array}$ \\
\hline
\end{tabular}

$100=100 \%$ of nutrient requirements; $100 \mathrm{E}=100 \%$ of nutrient requirements + Enzyme complex; $95=95 \%$ of nutrient requirements; $95 \mathrm{E}=95 \%$ of nutrient requirements + Enzyme complex; $90=90 \%$ of nutrient requirements; $90 \mathrm{E}=90 \%$ of nutrient requirements + Enzyme complex; ${ }^{1}$ Provided per kg of diet $=$ Fe -50 mg, Cu - 15 mg, Zn - 80 mg, Mn - 35 mg, I - 0.95 mg; ${ }^{2}$ Provided per kg of diet = Vit. A - 8000 Ul, Vit. D3 - 2000 Ul, Vit. E - 10 mg, Vit. K3 - 0.5 mg, Vit. B1 - 1.5 mg, Vit. B2 - 5 mg, Vit. B6 - 2 mg, Vit. B12 - 20 mcg, Niacin - 25 mg, Calcium pantothenate - 12 mg, Folic acid - 0.8 mg, Biotin - 0.05 mg, Se - 0.28 mg; ${ }^{3}$ Provided per

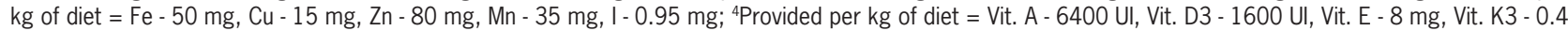
mg, Vit. B1 - 1.2 mg, Vit. B2 - 4 mg, Vit. B6 - 1.6 mg, Vit. B12 - 16 mcg, Niacin - 20 mg, Calcium pantothenate - 9.6 mg, Folic acid - 0.64 mg, Biotin - 0.04 mg, Se - $0.22 \mathrm{mg} ;{ }^{5}$ Provided per kg of diet = Iron - $40 \mathrm{mg}, \mathrm{Cu}-12 \mathrm{mg}, \mathrm{Zn}-64 \mathrm{mg}, \mathrm{Mn}-28 \mathrm{mg}, \mathrm{I}-0,76 \mathrm{mg}$; ${ }^{6}$ Provided per kg of diet = Vit. A - $4800 \mathrm{Ul}$, Vit. D3 - $1200 \mathrm{UI}$ Vit. E - 6 mg, Vit. K3 - 0.3 mg, Vit. B1 - 0.9 mg, Vit. B2 - 3 mg, Vit. B6 - 1.2 mg, Vit. B12 - 12 mcg, Niacin - 15 mg, Calcium pantothenate - 7.2 mg, Folic acid - 0.48 $\mathrm{mg}$, Biotin - $0.03 \mathrm{mg}$, Se - $0.17 \mathrm{mg} ;{ }^{*}$ Kaolin or kaolin + enzyme complex (200 g t${ }^{-1}$ ). 
the animals weighed $19.9 \pm 1.7 \mathrm{~kg}$ and ended when they reached $31.1 \pm 3.0 \mathrm{~kg}$ (50 to 66 days of age); Phase 2 was initiated when the animals weighed $31.1 \pm 3.0 \mathrm{~kg}$ and ended when they reached $70.3 \pm 6.4 \mathrm{~kg}$ (67 to 107 days of age); and Phase 3 was initiated when the animals weighed $70.3 \pm 6.4 \mathrm{~kg}$ and ended when they reached $96.5 \pm 9.0 \mathrm{~kg}$ (108 to 136 days of age). During the entire experiment, the animals had free access to the diets and water.

Table 2 - Analyzed chemical composition of pigs' diets in Phases 1 (19.90 \pm 1.67 to $31.13 \pm 2.95 \mathrm{~kg}$ of body weight - BW), 2 (31.13 \pm 2.95 to $70.34 \pm 6.36 \mathrm{~kg}$ of BW) and $3(70.34 \pm 6.36$ to 96.49 $\pm 8.98 \mathrm{~kg}$ of BW). Values expressed in dry matter basis.

\begin{tabular}{|c|c|c|c|c|c|c|}
\hline \multirow[b]{3}{*}{ Enzyme complex } & \multicolumn{6}{|c|}{ Nutritional levels } \\
\hline & \multicolumn{2}{|c|}{100} & \multicolumn{2}{|c|}{95} & \multicolumn{2}{|c|}{90} \\
\hline & + & - & + & - & + & - \\
\hline \multicolumn{7}{|l|}{ Phase 1} \\
\hline Dry matter (\%) & 89.4 & 89.1 & 89.3 & 89.0 & 89.2 & 89.7 \\
\hline Mineral matter (\%) & 6.27 & 5.90 & 5.92 & 7.13 & 7.62 & 8.05 \\
\hline Organic matter (\%) & 93.7 & 94.1 & 94.1 & 92.9 & 92.4 & 91.9 \\
\hline Nitrogen (\%) & 3.13 & 3.13 & 3.37 & 3.38 & 3.32 & 3.26 \\
\hline Phosphorous (g kg-1) & 10.05 & 9.78 & 9.71 & 9.46 & 9.41 & 9.21 \\
\hline Potassium ( $\mathrm{g} \mathrm{kg}^{-1}$ ) & 3.67 & 3.78 & 4.05 & 3.80 & 4.13 & 3.90 \\
\hline Calcium (g kg-1) & 7.76 & 8.00 & 8.49 & 7.89 & 8.43 & 8.44 \\
\hline Magnesium (g kg-1) & 2.22 & 2.08 & 2.74 & 2.36 & 3.14 & 3.57 \\
\hline $\operatorname{Zinc}\left(\mathrm{g} \mathrm{kg}^{-1}\right)$ & 0.13 & 0.14 & 0.15 & 0.14 & 0.14 & 0.14 \\
\hline Cupper (g kg-1) & 0.02 & 0.01 & 0.02 & 0.01 & 0.01 & 0.01 \\
\hline Sodium ( $\mathrm{g} \mathrm{kg}^{-1}$ ) & 1.73 & 1.49 & 1.58 & 1.54 & 1.58 & 1.50 \\
\hline Manganese $\left(\mathrm{g} \mathrm{kg}^{-1}\right)$ & 0.10 & 0.09 & 0.09 & 0.09 & 0.09 & 0.09 \\
\hline Iron $\left(\mathrm{g} \mathrm{kg}^{-1}\right)$ & 0.40 & 0.38 & 0.35 & 0.32 & 0.42 & 0.44 \\
\hline \multicolumn{7}{|l|}{ Phase 2} \\
\hline Dry matter (\%) & 89.9 & 89.7 & 89.5 & 88.8 & 89.1 & 88.9 \\
\hline Mineral matter (\%) & 5.57 & 5.47 & 5.65 & 5.93 & 7.09 & 7.47 \\
\hline Organic matter (\%) & 94.4 & 94.5 & 94.3 & 94.1 & 92.9 & 92.5 \\
\hline Nitrogen (\%) & 3.16 & 3.09 & 3.18 & 3.21 & 3.35 & 3.13 \\
\hline Phosphorous (g kg-1) & 9.43 & 9.12 & 9.32 & 9.33 & 9.08 & 9.02 \\
\hline Potassium $\left(\mathrm{g} \mathrm{kg}^{-1}\right)$ & 3.46 & 3.58 & 4.09 & 3.44 & 3.82 & 3.67 \\
\hline Calcium (g kg-1) & 8.10 & 7.86 & 7.79 & 7.49 & 8.18 & 8.56 \\
\hline Magnesium $\left(\mathrm{g} \mathrm{kg}^{-1}\right.$ ) & 1.97 & 2.00 & 1.92 & 1.82 & 4.35 & 4.25 \\
\hline $\operatorname{Zinc}\left(\mathrm{g} \mathrm{kg}^{-1}\right)$ & 0.12 & 0.15 & 0.13 & 0.12 & 0.14 & 0.12 \\
\hline Cupper (g kg-1) & 0.01 & 0.02 & 0.01 & 0.01 & 0.04 & 0.01 \\
\hline Sodium (g kg-1) & 1.37 & 1.40 & 1.31 & 1.24 & 1.38 & 1.38 \\
\hline Manganese $\left(\mathrm{g} \mathrm{kg}^{-1}\right.$ ) & 0.09 & 0.09 & 0.08 & 0.08 & 0.09 & 0.09 \\
\hline Iron $\left(\mathrm{g} \mathrm{kg}^{-1}\right)$ & 0.27 & 0.31 & 0.26 & 0.26 & 0.29 & 0.31 \\
\hline \multicolumn{7}{|l|}{ Phase 3} \\
\hline Dry matter (\%) & 89.9 & 89.0 & 89.3 & 89.9 & 89.9 & 89.9 \\
\hline Mineral matter (\%) & 5.90 & 5.22 & 5.94 & 5.87 & 7.67 & 7.66 \\
\hline Organic matter (\%) & 94.1 & 94.8 & 94.1 & 94.1 & 92.3 & 92.3 \\
\hline Nitrogen (\%) & 2.92 & 2.85 & 2.89 & 2.89 & 2.98 & 2.88 \\
\hline Phosphorous (g kg-1) & 8.86 & 8.69 & 9.21 & 8.82 & 8.87 & 8.66 \\
\hline Potassium ( $\mathrm{g} \mathrm{kg}^{-1}$ ) & 3.62 & 3.89 & 3.63 & 3.98 & 3.83 & 3.48 \\
\hline Calcium $\left(\mathrm{g} \mathrm{kg}^{-1}\right)$ & 7.26 & 7.03 & 8.15 & 6.87 & 7.64 & 7.35 \\
\hline Magnesium $\left(\mathrm{g} \mathrm{kg}^{-1}\right.$ ) & 1.94 & 1.87 & 2.31 & 2.20 & 3.41 & 3.27 \\
\hline $\operatorname{Zinc}\left(\mathrm{g} \mathrm{kg}^{-1}\right)$ & 0.11 & 0.12 & 0.12 & 0.12 & 0.13 & 0.11 \\
\hline Cupper $\left(\mathrm{g} \mathrm{kg}^{-1}\right.$ ) & 0.01 & 0.01 & 0.01 & 0.05 & 0.01 & 0.01 \\
\hline Sodium $\left(\mathrm{g} \mathrm{kg}^{-1}\right.$ ) & 1.04 & 1.23 & 1.32 & 1.24 & 1.08 & 1.08 \\
\hline Manganese $\left(\mathrm{g} \mathrm{kg}^{-1}\right)$ & 0.07 & 0.08 & 0.08 & 0.08 & 0.09 & 0.08 \\
\hline Iron $\left(\mathrm{g} \mathrm{kg}^{-1}\right)$ & 0.30 & 0.31 & 0.31 & 0.29 & 0.39 & 0.38 \\
\hline
\end{tabular}

Weight gain was determined by weighing the animals at the beginning and end of each phase. In each phase of the experiment, fecal excretions of dry matter (DM), mineral matter (MM), N, P, Ca, Mg, K, Na, Zn, Cu, Fe and Mn were estimated. Using these data, excretions were calculated for the following periods based on animal mass: Period 1: from $19.9 \pm 1.7$ to $31.1 \pm 3.0 \mathrm{~kg}$ (50 to 66 days of age); Period 1-2: from $19.9 \pm 1.7$ to 70.3 $\pm 6.4 \mathrm{~kg}$ (50 to 107 days of age); Period 1-3 (total): from $19.9 \pm 1.7$ to $96.5 \pm 9.0 \mathrm{~kg}$ (50 to 136 days of age).

Estimates of the excretions were performed when the animals reached the average expected weight for each phase by substituting part of the inert component of the diet with acid insoluble ash (AIA) over a period of 6 days. After the first 3 days in which AIA was included in the diets, fecal samples were collected over the following three consecutive days and frozen.

At the end of the collection period of each phase, animal feces were thawed, dried and ground; analyzed for DM, MM and $\mathrm{N}$; and subjected to nitro-perchloric digestion for the determination of $\mathrm{P}$ by colorimetry and the determination of $\mathrm{Ca}, \mathrm{Mg}, \mathrm{Na}, \mathrm{K}, \mathrm{Zn}, \mathrm{Cu}, \mathrm{Mn}$ and $\mathrm{Fe}$ by atomic absorption spectrophotometry (AOAC, 2006). The values of DM and MM were used for the calculation of the organic matter contents of the samples. The AIA determinations were performed according to van Keulen and Young (1977).

The indigestibility factor (IF) of the diets was calculated by dividing the AIA content in the diets by the AIA content in the feces, which corresponded to the portion of the diet that was not utilized by the animals and was therefore excreted in the feces. The IF values were used in combination with the feed consumption, which was determined as the difference between the quantity of feed provided and feed refused in each phase, to determine the fecal excretion using the following equation adapted from Marais (2000) as follows:

Fecal excretion on a DM basis $(\mathrm{kg})=$ Feed consumption on a DM basis*IF

The excretions of OM, MM, N and macro and micro minerals through the feces were obtained using the following equation:

Residue excretions $(\mathrm{g})=($ Fecal excretions on a DM basis $\times$ content of fecal residues)/100,

where, fecal residues $=\mathrm{OM}, \mathrm{MM}, \mathrm{N}, \mathrm{P}, \mathrm{Ca}, \mathrm{Mg}, \mathrm{K}, \mathrm{Na}$, $\mathrm{Zn}, \mathrm{Cu}, \mathrm{Fe}$ or $\mathrm{Mn}$, expressed as a percentage of fecal DM.

Based on these data, the average fecal production and the average excretions of OM, MM, N, macro and micro minerals through the feces were calculated for each treatment for periods 1, 1-2 and 1-3. The excretions of DM, MM, OM, N, macro and micro mineral in pigs feces per unit of weight gain, named "residue coefficient" $(\mathrm{RC})$, by treatment for periods 1, 1-2 and 1-3 were also calculated as follows: 
$\mathrm{RC}=$ Quantity of residues excreted through feces/ amount of live weight produced,

where residue $=\mathrm{DM}, \mathrm{MM}, \mathrm{OM}, \mathrm{N}$ or macro or micro minerals.

The anaerobic digestion of feces was evaluated using feces produced by the animals that were fed the $100,100 \mathrm{E}, 95$ and $95 \mathrm{E}$ diets. The following parameters were evaluated: biogas and methane production and production potential and the reduction in the contents of total solids (TS) and volatile solids (VS) of the substrate (feces and water).

In Phase 3, animal feces were collected from the floor of the animal pens, taking care to collect feces not contaminated with urine or feed waste. These feces were analyzed for TS and VS following the APHA method (2005) and then mixed with water to prepare substrates to supply the biodigesters (three per treatment), as shown in Table 3 . This material remained inside the biodigesters for 147 days. Each biodigester had the capacity to hold $50 \mathrm{~L}$ of substrate.

The volume of biogas produced weekly was determined by measuring the vertical displacement of the gasometers that covered the biodigesters and multiplying this result by 0.2827 , which was the area of the internal transverse section of the gasometers. After each measurement, the biogas was liberated through the discharge valve. The biogas volumes were corrected to 1 atm and $20{ }^{\circ} \mathrm{C}$ conditions. The methane $\left(\mathrm{CH}_{4}\right)$ contents of the biogas were also determined weekly using the GC-2001 gas chromatography equipment, with Porapack columns, a molecular sieve and a thermal conductivity detector.

The biogas and methane yields were calculated by dividing the respective volumes produced by the quantities in the feces in natura, in the substrate, in the TS and VS added to the biodigesters and in the VS reduced during the anaerobic digestion process. The values were expressed as $\mathrm{m}^{3}$ of biogas or methane per $\mathrm{kg}$ of feces, substrate, TS and VS added and VS reduced.

Table 3 - Composition of the substrates in the digesters prepared with feces of finishing pigs fed diets with different nutritional levels (100 or $95 \%$ ) with (+) or without (-) an enzyme complex.

\begin{tabular}{|c|c|c|c|c|}
\hline \multirow[b]{3}{*}{ Enzyme complex } & \multicolumn{4}{|c|}{ Nutritional levels } \\
\hline & \multicolumn{2}{|c|}{100} & \multicolumn{2}{|c|}{95} \\
\hline & + & - & + & - \\
\hline \multicolumn{5}{|l|}{ Components } \\
\hline Feces (kg) & 5.22 & 5.22 & 5.22 & 5.22 \\
\hline Water (kg) & 44.78 & 44.78 & 44.78 & 44.78 \\
\hline \multicolumn{5}{|l|}{ Determined composition } \\
\hline \multicolumn{5}{|l|}{ Total solids } \\
\hline$(\%)$ & 1.37 & 1.32 & 1.08 & 1.27 \\
\hline (kg) & 0.68 & 0.66 & 0.54 & 0.63 \\
\hline \multicolumn{5}{|l|}{ Volatile solids } \\
\hline (\% of total solids) & 84.57 & 83.28 & 82.90 & 93.18 \\
\hline (kg) & 0.58 & 0.55 & 0.45 & 0.53 \\
\hline
\end{tabular}

A completely randomized block design, based on the animal's initial weight, was used to evaluate residue excretions and residue coefficients, in a $3 \times 2$ factorial scheme (three nutrient levels with or without the enzyme complex) with nine repetitions and one animal per experimental unit. A completely randomized design was used to analyze the fecal anaerobic digestion trial, which consisted of four treatments arranged in a $2 \times 2$ factorial scheme (two nutrient levels with or without the enzyme complex) with three replicates per treatment.

All data were submitted to an analysis of variance using the General Linear Model from SAS (Statistical Analysis System, v. 9.1), and means comparisons were performed by Tukey test (5\%).

\section{Results and Discussion}

In Period 1, the animals that consumed diets 100 and 100E excreted less $(p<0.05)$ DM, OM, N, P, Fe, Na, $\mathrm{Mn}$ and $\mathrm{Cu}$, and showed lower $(p<0.05)$ coefficients of these residues than the animals which consumed the diets with 95 or $90 \%$ of the nutrient requirements (Tables 4 and 5). In Period 1-2, excretions of DM, OM, $\mathrm{MM}, \mathrm{N}, \mathrm{P}, \mathrm{Ca}, \mathrm{Mg}, \mathrm{Na}, \mathrm{Zn}, \mathrm{Mn}$ and $\mathrm{Cu}$, and coefficients of these residues, did not differ $(p>0.05)$ among the animals that were fed the diets with 100 and $95 \%$ of the nutrient requirements. However, pigs fed these diets had lower $(p<0.05)$ excretions than the pigs that consumed diets 90 and 90E (Tables 4 and 5). In Period 1-3, the same results were observed for $\mathrm{Zn}$ excretions and for $\mathrm{Zn}, \mathrm{Ca}$ and MM residue coefficients as were reported for Period 1-2 (Tables 4 and 5).

The effects of the enzyme complex on residue excretions were positive for a number of parameters. The addition of this product to the diets resulted in lower $(p<0.05)$ excretions and residue coefficients of OM and numerically lower excretions and residue coefficients of $\mathrm{N}(p=0.16$ and $p=0.13$, respectively) and of MM ( $p$ $=0.06$ and $p=0.08$, respectively) and lower excretion of $\mathrm{Zn}(p=0.09)$ in Period 1 (Tables 4 and 5). In Period $1-2$, the enzyme complex resulted in lower $(p<0.05) \mathrm{N}$, $\mathrm{Ca}, \mathrm{Zn}, \mathrm{Na}$ excretions and numerically lower excretions of DM $(p=0.10), \mathrm{MM}(p=0.17), \mathrm{OM}(p=0.08), \mathrm{P}(p$ $=0.14), \mathrm{K}(p=0.17), \mathrm{Mn}(p=0.06)$ and Fe $(p=0.07)$ (Table 4). In Period 1-3, the animals that consumed the diets with the enzyme complex had lower $(p<0.05)$ excretions and residue coefficients of $\mathrm{Na}$. In addition, in Period 1-3, animals that were fed the 95E diet had lower excretions $(p<0.05)$ of DM, OM, MM, N, Ca, Fe, Mn and $\mathrm{Cu}$, and lower residues coefficients $(p<0.05)$ of DM, OM, P, Fe, Mn and $\mathrm{Cu}$ compared with the animals that consumed the 95 diet (Tables 4 and 5).

It is worthwhile discussing the interaction between the factors that influenced excretion and residue coefficients in Period 1-3 (Tables 4 and 5). The positive effect of the enzyme complex was observed only at the $95 \%$ nutritional level. There was no effect of the enzyme complex at the $100 \%$ nutritional level 
Table 4 - The effects of diets with different nutritional levels (NI) with (+) or without $(-)$ an enzyme complex (Ec) on the excretion of dry matter (DM), mineral matter (MM), organic matter (OM), nitrogen (N) and minerals (P, K, Ca, Mg, Zn, Cu, Na, Mn and Fe) in feces of pigs from $19.9 \pm$ 1.7 to $31.1 \pm 3.0 \mathrm{~kg}$ of body weight - BW (Period 1), to $70.3 \pm 6.4 \mathrm{~kg}$ of BW (Period 1-2), and to $96.49 \pm 8.98 \mathrm{~kg}$ of BW (Period 1-3).

\begin{tabular}{|c|c|c|c|c|c|c|c|c|c|c|}
\hline \multirow{3}{*}{ Ec } & \multicolumn{6}{|c|}{$\mathrm{NI}$} & \multirow{3}{*}{$\mathrm{CV}^{1}(\%)$} & \multirow{2}{*}{\multicolumn{3}{|c|}{ Statistical Significance }} \\
\hline & \multicolumn{2}{|c|}{100} & \multicolumn{2}{|c|}{95} & \multicolumn{2}{|c|}{90} & & & & \\
\hline & + & - & + & - & + & - & & $\mathrm{Nl}$ & Ec & $\mathrm{Nl} \times \mathrm{Ec}$ \\
\hline \multicolumn{11}{|c|}{ Excretions } \\
\hline \multicolumn{11}{|l|}{ Period 1} \\
\hline DM (kg) & $2.63^{b}$ & $2.97^{b}$ & $3.99^{a}$ & $4.16^{a}$ & $4.05^{\mathrm{a}}$ & $4.19^{a}$ & 23.06 & ** & ns & ns \\
\hline $\mathrm{OM}(\mathrm{kg})$ & $2.22^{\mathrm{b}}$ & $2.80^{\mathrm{b}}$ & $3.80^{\mathrm{a}}$ & $3.7^{\mathrm{a}}$ & $3.38^{\mathrm{a}}$ & $4.05^{\mathrm{a}}$ & 17.10 & ** & * & ns \\
\hline MM (kg) & $0.41^{c}$ & $0.45^{c}$ & $0.57^{b}$ & $0.59^{b}$ & $0.68^{a}$ & $0.78^{a}$ & 20.67 & ** & ns & ns \\
\hline$N(g)$ & $97.6^{b}$ & $112^{\mathrm{b}}$ & $151^{\mathrm{a}}$ & $164^{a}$ & $146^{a}$ & $166^{a}$ & 29.28 & ** & ns & ns \\
\hline$P(g)$ & $65.3^{b}$ & $67.3^{\mathrm{b}}$ & $106^{\mathrm{a}}$ & $102^{\mathrm{a}}$ & $92.9^{a}$ & $105^{\mathrm{a}}$ & 23.52 & ** & ns & ns \\
\hline $\mathrm{Ca}(\mathrm{g})$ & $49.5^{\mathrm{bA}}$ & $51.3^{\mathrm{bA}}$ & $69.8^{\mathrm{abA}}$ & $64.5^{\mathrm{bA}}$ & $82.3^{\mathrm{aB}}$ & $121^{\mathrm{aA}}$ & 20.49 & ** & * & ** \\
\hline $\mathrm{K}(\mathrm{g})$ & $16.3^{\mathrm{b}}$ & $18.5^{\mathrm{b}}$ & $24.7^{\mathrm{a}}$ & $22.8^{a}$ & $17.8^{\mathrm{b}}$ & $17.3^{\mathrm{b}}$ & 18.42 & ** & ns & ns \\
\hline $\mathrm{Mg}(\mathrm{g})$ & $12.6^{c}$ & $13.5^{c}$ & $19.9^{b}$ & $19.4^{\mathrm{b}}$ & $31.2^{\mathrm{a}}$ & $34.8^{\mathrm{a}}$ & 20.73 & ** & ns & ns \\
\hline $\mathrm{Fe}(\mathrm{g})$ & $3.85^{b}$ & $4.16^{b}$ & $6.07^{a}$ & $6.01^{\mathrm{a}}$ & $5.53^{\mathrm{a}}$ & $5.52^{\mathrm{a}}$ & 46.36 & ** & ns & ns \\
\hline $\mathrm{Na}(\mathrm{g})$ & $2.25^{b}$ & $2.64^{b}$ & $3.92^{\mathrm{a}}$ & $4.60^{\mathrm{a}}$ & $4.22^{\mathrm{a}}$ & $3.82^{\mathrm{a}}$ & 28.11 & ** & ns & ns \\
\hline $\mathrm{Zn}(\mathrm{g})$ & 2.32 & 2.93 & 2.70 & 2.65 & 2.22 & 2.63 & 42.72 & ns & ns & ns \\
\hline $\mathrm{Mn}(\mathrm{g})$ & $0.81^{\mathrm{b}}$ & $0.87^{b}$ & $1.36^{\mathrm{a}}$ & $1.44^{\mathrm{a}}$ & $1.28^{\mathrm{a}}$ & $1.35^{\mathrm{a}}$ & 28.31 & ** & ns & ns \\
\hline $\mathrm{Cu}(\mathrm{g})$ & $0.26^{b}$ & $0.27^{b}$ & $0.43^{\mathrm{a}}$ & $0.42^{\mathrm{a}}$ & $0.40^{a}$ & $0.44^{a}$ & 28.77 & ** & ns & ns \\
\hline \multicolumn{11}{|c|}{ Period 1-2 } \\
\hline DM (kg) & $16.2^{\mathrm{b}}$ & $16.7^{b}$ & $16.5^{b}$ & $19.0^{\mathrm{b}}$ & $25.6^{a}$ & $26.7^{\mathrm{a}}$ & 16.91 & ** & ns & ns \\
\hline OM (kg) & $13.7^{\mathrm{b}}$ & $14.3^{b}$ & $14.4^{b}$ & $16.5^{b}$ & $21.0^{a}$ & $22.1^{\mathrm{a}}$ & 14.56 & ** & ns & ns \\
\hline MM (kg) & $2.53^{b}$ & $2.66^{b}$ & $2.58^{b}$ & $2.95^{\mathrm{b}}$ & $4.92^{\mathrm{a}}$ & $4.96^{a}$ & 17.85 & ** & ns & ns \\
\hline$N(g)$ & $545^{b}$ & $582^{\mathrm{b}}$ & $575^{b}$ & $730^{b}$ & $832^{a}$ & $886^{a}$ & 16.23 & ** & * & ns \\
\hline$P(g)$ & $385^{b}$ & $411^{\mathrm{b}}$ & $419^{b}$ & $470^{\mathrm{b}}$ & $568^{a}$ & $594^{a}$ & 17.05 & ** & ns & ns \\
\hline $\mathrm{Ca}$ (g) & $314^{b}$ & $333^{b}$ & $330^{\mathrm{b}}$ & $398^{b}$ & $723^{a}$ & $794^{a}$ & 17.88 & ** & * & ns \\
\hline K (g) & 106 & 110 & 104 & 116 & 112 & 117 & 16.30 & ns & ns & ns \\
\hline $\operatorname{Mg}(g)$ & $83.6^{\mathrm{b}}$ & $94.5^{b}$ & $99.0^{\mathrm{b}}$ & $114^{\mathrm{b}}$ & $255^{a}$ & $256^{a}$ & 19.25 & ** & ns & ns \\
\hline $\mathrm{Fe}(\mathrm{g})$ & $19.3^{b}$ & $23.4^{b}$ & $20.9^{b}$ & $26.8^{\mathrm{b}}$ & $34.4^{a}$ & $33.9^{\mathrm{a}}$ & 19.37 & ** & ns & ns \\
\hline $\mathrm{Na}(\mathrm{g})$ & $12.3^{\mathrm{b}}$ & $15.9^{b}$ & $16.5^{\mathrm{a}}$ & $21.7^{a}$ & $19.9^{a}$ & $22.7^{\mathrm{a}}$ & 21.45 & ** & * & ns \\
\hline Zn (g) & $10.4^{b}$ & $12.9^{b}$ & $10.8^{b}$ & $11.9^{\mathrm{b}}$ & $13.9^{a}$ & $14.1^{\mathrm{a}}$ & 41.94 & ** & * & ns \\
\hline $\mathrm{Mn}(\mathrm{g})$ & $6.19^{b}$ & $7.51^{\mathrm{b}}$ & $6.61^{b}$ & $7.92^{\mathrm{b}}$ & $10.9^{a}$ & $10.7^{a}$ & 17.42 & ** & ns & ns \\
\hline $\mathrm{Cu}(\mathrm{g})$ & $1.77^{\mathrm{b}}$ & $1.82^{\mathrm{b}}$ & $1.94^{b}$ & $2.24^{b}$ & $2.94^{\mathrm{a}}$ & $2.90^{\mathrm{a}}$ & 22.07 & ** & ns & ns \\
\hline \multicolumn{11}{|c|}{ Period 1-3 } \\
\hline DM (kg) & $30.0^{\mathrm{bA}}$ & $29.8^{\mathrm{bA}}$ & $31.2^{\mathrm{bB}}$ & $35.2^{\mathrm{bA}}$ & $47.4^{\mathrm{aA}}$ & $43.2^{\mathrm{aB}}$ & 12.19 & ** & ns & * \\
\hline OM (kg) & $25.3^{\mathrm{bA}}$ & $25.3^{\mathrm{bA}}$ & $26.7^{\mathrm{bB}}$ & $31.4^{\mathrm{aA}}$ & $38.4^{\mathrm{aA}}$ & $35.2^{\mathrm{aA}}$ & 10.08 & ** & ns & * \\
\hline MM (kg) & $4.68^{\mathrm{bA}}$ & $4.73^{\mathrm{bA}}$ & $4.86^{\mathrm{bB}}$ & $5.47^{\mathrm{bA}}$ & $9.19^{\mathrm{aA}}$ & $8.47^{a B}$ & 10.96 & ** & ns & * \\
\hline$N(\mathrm{~kg})$ & $0.97^{\mathrm{bA}}$ & $0.97^{\mathrm{bA}}$ & $1.01^{\mathrm{bB}}$ & $1.25^{\mathrm{abA}}$ & $1.47^{\mathrm{aA}}$ & $1.34^{\mathrm{aA}}$ & 15.08 & ** & ns & * \\
\hline$P(k g)$ & $0.73^{c}$ & $0.72^{c}$ & $0.79^{b}$ & $0.90^{\mathrm{b}}$ & $1.09^{a}$ & $1.02^{\mathrm{a}}$ & 12.08 & ** & ns & ns \\
\hline $\mathrm{Ca}(\mathrm{kg})$ & $0.55^{\mathrm{bA}}$ & $0.61^{\mathrm{bA}}$ & $0.61^{\mathrm{bB}}$ & $0.71^{\mathrm{bA}}$ & $1.38^{\mathrm{aA}}$ & $1.31^{\text {aA }}$ & 15.98 & ** & ns & * \\
\hline $\mathrm{K}(\mathrm{g})$ & 196 & 191 & 205 & 222 & 202 & 213 & 4.37 & ns & ns & ns \\
\hline $\mathrm{Mg}(\mathrm{g})$ & $153^{c}$ & $147^{c}$ & $171^{\mathrm{b}}$ & $193^{b}$ & $427^{a}$ & $420^{a}$ & 17.80 & ** & ns & ns \\
\hline $\mathrm{Fe}(\mathrm{g})$ & $36.9^{\mathrm{bA}}$ & $41.4^{\mathrm{bA}}$ & $38.3^{\mathrm{bB}}$ & $49.0^{\mathrm{abA}}$ & $59.1^{\mathrm{aA}}$ & $54.2^{\mathrm{aA}}$ & 16.11 & ** & ns & * \\
\hline $\mathrm{Na}(\mathrm{g})$ & $35.6^{b}$ & $39.5^{b}$ & $39.9^{a}$ & $58.5^{a}$ & $43.6^{\mathrm{ab}}$ & $49.8^{\mathrm{ab}}$ & 11.75 & * & * & ns \\
\hline Zn (g) & $17.3^{b}$ & $18.3^{b}$ & $17.9^{b}$ & $20.1^{\mathrm{b}}$ & $21.8^{a}$ & $21.4^{\mathrm{a}}$ & 30.59 & ** & ns & ns \\
\hline Mn (g) & $10.4^{\mathrm{bA}}$ & $11.3^{\mathrm{bA}}$ & $11.0^{\mathrm{bB}}$ & $13.5^{\mathrm{abA}}$ & $17.9^{\mathrm{aA}}$ & $15.6^{\mathrm{aB}}$ & 12.72 & ** & ns & ** \\
\hline $\mathrm{Cu}(\mathrm{g})$ & $3.06^{\mathrm{bA}}$ & $2.90^{\mathrm{bA}}$ & $3.04^{\mathrm{bB}}$ & $3.78^{\mathrm{aA}}$ & $5.08^{\mathrm{aA}}$ & $4.46^{\mathrm{aB}}$ & 15.38 & ** & ns & ** \\
\hline
\end{tabular}

${ }^{1} \mathrm{CV}=$ Coefficient of variation; abcValues within a row, by Enzyme Complex, with different superscripts which differ significantly at $p<0.05$; ABValues within a row, by Nutritional Level, with different superscripts which differ significantly at $p<0.05 ;{ }^{*} p<0.05 ;{ }^{*} p<0.01$; ns = non significant.

on $\mathrm{OM}, \mathrm{Ca}, \mathrm{N}$ or $\mathrm{Fe}$, but the enzyme complex did result in greater $\mathrm{DM}, \mathrm{MM}, \mathrm{Cu}$ and $\mathrm{Mn}$ excretions at the $90 \%$ nutritional level. First, in the diets formulated to achieve $100 \%$ of the nutrient requirements, the improvement in the availability of nutrients and energy as a result of the enzyme complex was reflected in nutrients in excess of the animal's nutrient requirements. These excess nutrients would have been excreted if they had not been 
Table 5 - The effects of diets with different nutritional levels (NI) with (+) or without (-) an enzyme complex (EC) on the residues coefficient (RC), of dry matter (DM), mineral matter (MM), organic matter (OM), nitrogen (N), macro and micro mineral of pigs from $19.90 \pm 1.67$ to $31.13 \pm$ $2.95 \mathrm{~kg}$ of body weight - BW (Period 1), to $70.34 \pm 6.36 \mathrm{~kg}$ of BW (Period 1-2), and to $96.49 \pm 8.98 \mathrm{~kg}$ of BW (Period 1-3).

\begin{tabular}{|c|c|c|c|c|c|c|c|c|c|c|}
\hline \multirow{3}{*}{ Ec } & \multicolumn{6}{|c|}{$\mathrm{NI}$} & \multirow{3}{*}{$\mathrm{CV}^{1}(\%)$} & \multirow{2}{*}{\multicolumn{3}{|c|}{ Statistical Significance }} \\
\hline & \multicolumn{2}{|c|}{100} & \multicolumn{2}{|c|}{95} & \multicolumn{2}{|c|}{90} & & & & \\
\hline & + & - & + & - & + & - & & $\mathrm{Nl}$ & Ec & $\mathrm{Nl} \times \mathrm{EC}$ \\
\hline \multicolumn{11}{|c|}{$\mathrm{RC}^{2}\left(\mathrm{~g} \mathrm{~kg}^{-1}\right)$} \\
\hline \multicolumn{11}{|c|}{ Period 1} \\
\hline DM & $241^{c}$ & $281^{c}$ & $314^{b}$ & $365^{b}$ & $405^{a}$ & $401^{\mathrm{a}}$ & 22.68 & ** & ns & ns \\
\hline $\mathrm{OM}$ & $204^{b}$ & $266^{b}$ & $300^{a}$ & $349^{a}$ & $337^{a}$ & $364^{a}$ & 18.08 & ** & * & ns \\
\hline MM & $37.5^{c}$ & $42.6^{c}$ & $47.2^{\mathrm{b}}$ & $52.2^{\mathrm{b}}$ & $68.3^{a}$ & $72.5^{\mathrm{a}}$ & 24.54 & ** & ns & ns \\
\hline $\mathrm{N}$ & $8.93^{b}$ & $10.5^{b}$ & $11.8^{a}$ & $14.4^{\mathrm{a}}$ & $14.5^{\mathrm{a}}$ & $14.5^{\mathrm{a}}$ & 25.89 & ** & ns & ns \\
\hline$P$ & $5.96^{b}$ & $6.36^{b}$ & $8.28^{a}$ & $8.89^{a}$ & $9.33^{a}$ & $9.17^{\mathrm{a}}$ & 20.46 & ** & ns & ns \\
\hline $\mathrm{Ca}$ & $5.01^{\mathrm{bA}}$ & $4.84^{\mathrm{bA}}$ & $5.54^{\mathrm{bA}}$ & $5.67^{\mathrm{bA}}$ & $8.28^{\mathrm{aB}}$ & $11.2^{\mathrm{aA}}$ & 26.33 & ** & * & * \\
\hline K & 1.50 & 1.79 & 1.84 & 2.02 & 1.85 & 1.43 & 24.43 & ns & ns & ns \\
\hline $\mathrm{Mg}$ & $1.18^{\mathrm{bA}}$ & $1.27^{\mathrm{bA}}$ & $1.56^{\mathrm{bA}}$ & $1.72^{\mathrm{bA}}$ & $3.43^{\mathrm{aA}}$ & $2.98^{\mathrm{aB}}$ & 18.82 & ** & ns & $*$ \\
\hline $\mathrm{Fe}$ & $0.36^{\mathrm{b}}$ & $0.40^{\mathrm{b}}$ & $0.49^{a}$ & $0.59^{a}$ & $0.54^{\mathrm{a}}$ & $0.49^{a}$ & 50.79 & ** & ns & ns \\
\hline $\mathrm{Na}$ & $0.22^{\mathrm{bA}}$ & $0.24^{\mathrm{aA}}$ & $0.31^{\mathrm{abA}}$ & $0.40^{\mathrm{aA}}$ & $0.42^{\mathrm{aA}}$ & $0.29^{\mathrm{aB}}$ & 24.61 & ** & ns & $*$ \\
\hline $\mathrm{Zn}$ & 0.22 & 0.27 & 0.24 & 0.24 & 0.22 & 0.23 & 50.49 & ns & ns & ns \\
\hline $\mathrm{Mn}$ & $0.08^{b}$ & $0.08^{b}$ & $0.11^{\mathrm{a}}$ & $0.13^{a}$ & $0.13^{a}$ & $0.12^{\mathrm{a}}$ & 24.65 & ** & ns & ns \\
\hline $\mathrm{Cu}$ & $0.02^{\mathrm{b}}$ & $0.03^{b}$ & $0.04^{\mathrm{a}}$ & $0.04^{\mathrm{a}}$ & $0.04^{\mathrm{a}}$ & $0.04^{\mathrm{a}}$ & 30.38 & ** & ns & ns \\
\hline \multicolumn{11}{|c|}{ Period 1-2 } \\
\hline DM & $320^{b}$ & $320^{b}$ & $313^{b}$ & $372^{b}$ & $544^{a}$ & $509^{a}$ & 16.30 & ** & ns & ns \\
\hline $\mathrm{OM}$ & $270^{b}$ & $274^{b}$ & $272^{b}$ & $322^{b}$ & $442 .{ }^{a}$ & $419^{a}$ & 14.29 & ** & ns & ns \\
\hline MM & $49.8^{b}$ & $51.0^{\mathrm{b}}$ & $48.9^{b}$ & $57.5^{b}$ & $102^{a}$ & $98.2^{\mathrm{a}}$ & 17.46 & ** & ns & ns \\
\hline$N$ & $10.7^{b}$ & $11.1^{\mathrm{b}}$ & $10.9^{b}$ & $13.1^{\mathrm{b}}$ & $18.5^{\mathrm{a}}$ & $16.7^{\mathrm{a}}$ & 22.02 & ** & ns & ns \\
\hline$P$ & $7.76^{b}$ & $7.85^{b}$ & $7.92^{\mathrm{b}}$ & $9.17^{b}$ & $12.1^{\mathrm{a}}$ & $11.7^{\mathrm{a}}$ & 16.01 & ** & ns & ns \\
\hline $\mathrm{Ca}$ & $6.30^{\mathrm{b}}$ & $6.35^{b}$ & $6.23^{b}$ & $7.71^{\mathrm{b}}$ & $15.5^{\mathrm{a}}$ & $16.2^{\mathrm{a}}$ & 17.01 & ** & ns & ns \\
\hline K & 2.12 & 2.09 & 2.08 & 2.25 & 2.28 & 2.35 & 17.86 & ns & ns & ns \\
\hline $\mathrm{Mg}$ & $1.69^{\mathrm{b}}$ & $1.82^{\mathrm{b}}$ & $1.96^{\mathrm{b}}$ & $2.25^{b}$ & $5.28^{\mathrm{a}}$ & $5.05^{\mathrm{a}}$ & 18.15 & ** & ns & ns \\
\hline $\mathrm{Fe}$ & $0.39^{\mathrm{bA}}$ & $0.45^{\mathrm{aA}}$ & $0.40^{\mathrm{bB}}$ & $0.52^{\mathrm{aA}}$ & $0.73^{\mathrm{aA}}$ & $0.62^{\mathrm{aA}}$ & 21.40 & ** & ns & $*$ \\
\hline $\mathrm{Na}$ & $0.26^{\mathrm{b}}$ & $0.31^{\mathrm{b}}$ & $0.33^{\mathrm{ab}}$ & $0.42^{\mathrm{ab}}$ & $0.41^{\mathrm{a}}$ & $0.42^{\mathrm{a}}$ & 15.70 & * & ns & ns \\
\hline $\mathrm{Zn}$ & $0.20^{\mathrm{bB}}$ & $0.25^{\mathrm{aA}}$ & $0.22^{\mathrm{bA}}$ & $0.23^{\mathrm{aA}}$ & $0.30^{\mathrm{aA}}$ & $0.28^{\mathrm{aA}}$ & 42.73 & ** & ns & * \\
\hline $\mathrm{Mn}$ & $0.13^{\mathrm{bA}}$ & $0.13^{\mathrm{bA}}$ & $0.11^{\mathrm{bB}}$ & $0.15^{\mathrm{abA}}$ & $0.23^{\mathrm{aA}}$ & $0.20^{\mathrm{aA}}$ & 22.50 & ** & ns & * \\
\hline $\mathrm{Cu}$ & $0.04^{b}$ & $0.04^{b}$ & $0.04^{b}$ & $0.04^{b}$ & $0.06^{a}$ & $0.06^{a}$ & 25.65 & ** & ns & ns \\
\hline \multicolumn{11}{|c|}{ Period 1-3 } \\
\hline DM & $387^{\mathrm{bA}}$ & $374^{\mathrm{bA}}$ & $392^{\mathrm{bB}}$ & $445^{\mathrm{bA}}$ & $639^{\mathrm{aA}}$ & $583^{a B}$ & 12.25 & ** & ns & * \\
\hline $\mathrm{OM}$ & $326^{\mathrm{bA}}$ & $318^{\mathrm{bA}}$ & $336^{\mathrm{bB}}$ & $381^{\mathrm{bA}}$ & $514^{\mathrm{aA}}$ & $474^{\mathrm{aA}}$ & 10.57 & ** & ns & * \\
\hline MM & $60.3^{\mathrm{b}}$ & $59.5^{\mathrm{b}}$ & $61.3^{b}$ & $69.4^{b}$ & $120^{a}$ & $114^{a}$ & 12.68 & ** & ns & ns \\
\hline $\mathrm{N}$ & $12.5^{\mathrm{bA}}$ & $12.1^{\mathrm{bA}}$ & $12.7^{\mathrm{bA}}$ & $14.7 \mathrm{abA}$ & $20.5^{\mathrm{aA}}$ & $18.1^{\mathrm{aA}}$ & 17.19 & ** & ns & * \\
\hline$P$ & $9.47^{\mathrm{bA}}$ & $9.03^{\mathrm{cA}}$ & $9.89^{\mathrm{bB}}$ & $11.4^{\mathrm{bA}}$ & $15.4^{\mathrm{aA}}$ & $13.8^{\mathrm{aB}}$ & 11.45 & ** & ns & ** \\
\hline $\mathrm{Ca}$ & $7.71^{b}$ & $7.66^{b}$ & $7.67^{b}$ & $8.95^{b}$ & $17.8^{\mathrm{a}}$ & $18.1^{\mathrm{a}}$ & 17.47 & ** & ns & ns \\
\hline K & $2.55^{b}$ & $2.43^{b}$ & $2.68^{\mathrm{ab}}$ & $2.80^{\mathrm{ab}}$ & $2.85^{a}$ & $2.85^{\mathrm{a}}$ & 12.96 & * & ns & ns \\
\hline $\mathrm{Mg}$ & $2.02^{c}$ & $1.95^{c}$ & $2.22^{b}$ & $2.46^{b}$ & $6.04^{\mathrm{a}}$ & $5.66^{a}$ & 12.20 & ** & ns & ns \\
\hline $\mathrm{Fe}$ & $0.47^{\mathrm{bA}}$ & $0.52^{\mathrm{bA}}$ & $0.48^{B}$ & $0.59 \mathrm{abA}$ & $0.83^{\mathrm{aA}}$ & $0.70^{\mathrm{aB}}$ & 14.48 & ** & ns & ** \\
\hline $\mathrm{Na}$ & $0.47^{\mathrm{b}}$ & $0.50^{\mathrm{b}}$ & $0.50^{a}$ & $0.74^{\mathrm{a}}$ & $0.53^{\mathrm{ab}}$ & $0.67^{\mathrm{ab}}$ & 12.44 & * & ** & ns \\
\hline $\mathrm{Zn}$ & $0.22^{\mathrm{b}}$ & $0.23^{b}$ & $0.23^{b}$ & $0.25^{\mathrm{b}}$ & $0.30^{\mathrm{a}}$ & $0.29^{a}$ & 35.65 & ** & ns & ns \\
\hline $\mathrm{Mn}$ & $0.13^{\mathrm{bA}}$ & $0.14^{\mathrm{bA}}$ & $0.13^{\mathrm{bB}}$ & $0.16^{\mathrm{bA}}$ & $0.24^{\mathrm{aA}}$ & $0.20^{\mathrm{aB}}$ & 16.57 & ** & ns & ** \\
\hline $\mathrm{Cu}$ & $0.04^{\mathrm{bA}}$ & $0.04^{\mathrm{bA}}$ & $0.04^{\mathrm{bB}}$ & $0.05^{\mathrm{bA}}$ & $0.07^{\mathrm{aA}}$ & $0.06^{\mathrm{aB}}$ & 17.86 & ** & ns & ** \\
\hline
\end{tabular}

absorbed. This finding may indicate that the exogenous enzymes used in diets with adequate nutrient levels do not necessarily imply an improvement in feed efficiency and, thus, lower residue excretions.
For the diets with $90 \%$ of the nutrient requirements, it is possible that there was such a severe decrease in the digestibility of the diet that even the expected positive effects of the enzyme complex were not observed. It 
is also possible that the action of the enzyme complex involved in making nutrients available was much lower than needed to reverse the $10 \%$ reduction in the nutrient levels of the diets and to improve the use of the diets and hence lower residue excretions. Based on these assumptions, the addition of the enzyme complex to diets with drastic nutrient reductions does not result in positive responses but, rather, in the main, increases residue excretions.

The positive results obtained in this research are in accordance with those found in the literature. Moeser et al. (2002) verified that the addition of xylanase to diets with $22 \%$ of neutral detergent fiber reduced the quantities of feces excreted by pigs by $10 \%$ compared to the feces excreted by pigs fed a diet with the same fiber level but without the enzyme. Zhang et al. (2003) evaluated the effects of pea micronization and enzyme supplementation ( $\beta$-glucanase, phytase, protease, amylase, cellulase and pectinase) on $\mathrm{N}$ and $\mathrm{P}$ excretions by growing pigs. The authors verified that pea micronization and the use of the enzymes reduced $\mathrm{N}$, $\mathrm{P}$ and fecal excretions by an average of 25,20 and 16 $\%$, respectively, relative to the animals that were fed a control diet (with regular peas and without enzymes). Similarly, Htoo et al. (2007) verified that pigs fed a low-P diet composed of barley and soybean meal and supplemented with phytase excreted $32 \%$ less $\mathrm{P}$ than the animals that consumed a diet with regular $\mathrm{P}$ levels and without enzymes.

In the present study, the anaerobic biodigestion of the animal's feces was not affected $(p>0.05)$ by the different experimental diets (Table 6). However, the use of the feces from the pigs fed the diet with the enzyme complex numerically improved biogas yields per $\mathrm{kg}$ of TS, VS and reduced VS by $20 \%(p=0.13), 19 \%(p=$
$0.15)$ and $22 \%(p=0.19)$, and methane yields per $\mathrm{kg}$ of TS, VS and reduced VS by $22 \%(p=0.13), 20 \%(p=$ $0.15)$ and $23 \%(p=0.19)$, respectively, compared to the feces from the animals that consumed the diets without enzymes.

The anaerobic biodigestion process occurs as a result of the action of different microorganisms on organic matter, which transforms complex organic substances into more simple molecules, stabilizing the organic matter and producing biofertilizer and biogas (Amorim et al., 2004). Many factors can affect this process, including the composition of the substrate to be digested, which is closely related to the diets fed to animals. The mineral and nitrogen contents and the different types of carbohydrates in the diets affect the amount and quality of feces produced, and can therefore alter biogas production (Orrico et al., 2007).

Considering the carbohydrates present in diets fed to pigs, starch is totally digested in the pig's small and large intestine, whereas the fibrous component of the feedstuffs is partially degraded in the large intestine, and the portion not completely digested is, most likely, excreted (Wang et al., 2002). In phase 3 diets of this research, the calculated values of total carbohydrates, non-fibrous carbohydrates and neutral detergent fiber (Table 1) ranged from 60 to $62 \%$, from 43 to $44 \%$, and from 17 to $18 \%$, respectively.

One of the expected actions of the enzyme complex was the degradation of fibrous carbohydrates in the feed offered to the animals in such a way that they could be used as a source of energy and would not cause negative effects in the digestion of other components of the diet. Choct (2006) and Adeola and Cowieson (2011) noted that the majority of the carbohydrases employed in animal

Table 6 - The effects of diets with different nutritional levels (NI) with (+) or without (-) an enzyme complex (Ec) on anaerobic biodigestion of feces from finishing pigs.

\begin{tabular}{|c|c|c|c|c|c|c|c|c|}
\hline \multirow{3}{*}{ Ec } & \multicolumn{4}{|c|}{$\mathrm{Nl}$} & \multirow{3}{*}{$\mathrm{CV}^{1}(\%)$} & \multirow{2}{*}{\multicolumn{3}{|c|}{ Statistical Significance }} \\
\hline & \multicolumn{2}{|c|}{100} & \multicolumn{2}{|c|}{95} & & & & \\
\hline & + & - & + & - & & $\mathrm{NI}$ & Ec & $\mathrm{Nl} \times \mathrm{Ec}$ \\
\hline Total solid reduction (\%) & 60.0 & 53.7 & 54.6 & 60.9 & 12.96 & ns & ns & ns \\
\hline Volatile solid reduction (\%) & 68.4 & 61.3 & 62.1 & 69.5 & 9.11 & ns & ns & ns \\
\hline Volatile solid reduction (kg) & 0.41 & 0.34 & 0.28 & 0.37 & 25.44 & ns & ns & ns \\
\hline Biogas production $\left(\mathrm{m}^{3}\right)$ & 0.47 & 0.36 & 0.47 & 0.46 & 17.73 & ns & ns & ns \\
\hline Methane production $\left(\mathrm{m}^{3}\right)$ & 0.37 & 0.28 & 0.36 & 0.35 & 17.74 & ns & ns & ns \\
\hline \multicolumn{9}{|l|}{ Biogas yield } \\
\hline $\mathrm{m}^{3} \mathrm{~kg}$ added total solids ${ }^{-1}$ & 0.69 & 0.57 & 0.86 & 0.72 & 18.88 & ns & ns & ns \\
\hline $\mathrm{m}^{3} \mathrm{~kg}$ added volatile solids ${ }^{-1}$ & 0.82 & 0.69 & 1.04 & 0.87 & 19.43 & ns & ns & ns \\
\hline $\mathrm{m}^{3} \mathrm{~kg}$ volatile solids reduced ${ }^{-1}$ & 1.23 & 1.13 & 1.68 & 1.25 & 24.02 & ns & ns & ns \\
\hline $\mathrm{m}^{3} \mathrm{~kg}$ feces $^{-1}$ & 0.09 & 0.07 & 0.09 & 0.09 & 17.54 & ns & ns & ns \\
\hline \multicolumn{9}{|l|}{ Methane yield } \\
\hline $\mathrm{m}^{3} \mathrm{~kg}$ added total solids ${ }^{-1}$ & 0.54 & 0.45 & 0.67 & 0.56 & 18.99 & ns & ns & ns \\
\hline $\mathrm{m}^{3} \mathrm{~kg}$ added volatile solids ${ }^{-1}$ & 0.64 & 0.54 & 0.81 & 0.68 & 19.57 & ns & ns & ns \\
\hline $\mathrm{m}^{3} \mathrm{~kg}$ volatile solids reduced ${ }^{-1}$ & 0.96 & 0.88 & 1.31 & 0.98 & 17.95 & ns & ns & ns \\
\hline $\mathrm{m}^{3} \mathrm{~kg} \mathrm{feces}^{-1}$ & 0.07 & 0.05 & 0.07 & 0.07 & 17.71 & ns & ns & ns \\
\hline
\end{tabular}

${ }^{1} \mathrm{CV}=$ Coefficient of variation; $\mathrm{ns}=$ non significant. 
feeding are endoenzymes, which cleave the carbohydrate in the middle of the chain and do not immediately liberate its forming units. Thus, it may be that the action of the carbohydrases, which are mainly endoenzymes, would liberate part of the fibrous carbohydrate molecules that may or may not be enzymatically used by the pig or by its intestinal microbial population. In other words, the carbohydrate portions liberated by the exogenous enzymes may be a source of energy for the animal or may simply be excreted.

Nevertheless, even if excreted, it is possible that these components of carbohydrates may be more accessible for microbial degradation in the biodigesters than intact fiber molecules. Thus, the numerical differences in biogas and methane yields from the feces of the pigs fed the diets which contained the enzyme complex may be credited to the presence of more easily digestible carbohydrates as a consequence of the action of the enzyme complex.

An interesting observation is the relationship between the components of the fecal excretions and the biogas and methane production potentials. Considering the organic matter excreted in Period 1-3 by the animals that consumed the $95 \mathrm{E}$ and 95 diets, which differed significantly, and relating this pattern to the biogas and methane yields per $\mathrm{kg}$ of volatile solids, it was possible to conclude that the total production of biogas and methane was very similar.

The animals fed the 95E diet excreted an average of $26.7 \mathrm{~kg}$ of organic matter, and their feces showed biogas and methane yields of 1.04 and $0.81 \mathrm{~m}^{3} \mathrm{~kg}^{-1}$ of volatile solids, respectively. It is possible, through the biodigestion process, that this quantity of organic matter could result in the production of $27.8 \mathrm{~m}^{3}$ of biogas and $21.6 \mathrm{~m}^{3}$ of methane. The animals fed the 95 diet had an organic matter excretion of $31.4 \mathrm{~kg}$ and biogas and methane yields of 0.87 and $0.68 \mathrm{~m}^{3} \mathrm{~kg}^{-1}$ of volatile solids, respectively. Similarly, the organic matter excreted by these animals could potentially produce $27.3 \mathrm{~m}^{3}$ of biogas and $21.4 \mathrm{~m}^{3}$ of methane.

Thus, the use of the enzyme complex in the diet that achieved $95 \%$ of the nutritional requirements reduced the excretion of organic matter, but the feces of the animals that consumed this diet could potentially produce similar volumes of biogas and methane compared to the feces of the animals that were fed the 95 diet, which excreted a greater quantity of organic matter. In other words, the enzyme supplement was able to lower organic matter excretion, and reduce the potential environmental impact of pig manure but maintain biogas and methane production.

In researches evaluating the anaerobic digestion of pig feces, it is difficult to find a description of the diets fed to the animals. However, the biodigestion of feces from pigs fed diets with corn or sorghum, as energy sources, was evaluated by Orrico et al. (2010) and Miranda et al. (2012). These authors found that the feces of the pigs fed the corn diets presented greater total and volatile solid reductions and had greater yields of biogas and methane than the feces of pigs fed the sorghum diets, showing that diet composition affects feces biodigestion.

Orrico et al. (2010) reported that biogas yields per $\mathrm{kg}$ of TS and reduced VS with hydraulic retention times (HRT) from 30 to 120 days ranged from 0.684 to $1.225 \mathrm{~m}^{3}$ and from 0.523 to $0.963 \mathrm{~m}^{3}$, respectively, for the feces of pigs fed a corn-based diet and from 0.822 to $1.336 \mathrm{~m}^{3}$ and 0.477 to $0.900 \mathrm{~m}^{3}$, respectively, for the manure of the animals that consumed the sorghum diet. In contrast, Miranda et al. (2012) reported biogas yields per $\mathrm{kg}$ of added TS and VS and reduced VS of 0.525 , $0.599,0.872 \mathrm{~m}^{3}$, respectively, for the feces of pigs fed the corn diets, and $0.499,0.563,0.904 \mathrm{~m}^{3}$, respectively, for the feces of the pigs fed the sorghum diet. These values were lower than those reported by Orrico et al. (2010) and the findings of the current research, which may be related to the shorter HRT used by Miranda et al. (2012) that was approximately 30 days. In the work of Orrico et al. (2010), as in the current research, the HRT used was longer, allowing for greater total biogas and methane production, which, when divided by the quantities of the added substrate, generated higher values.

It is also important to reinforce that there were no differences in growth performance of pigs fed diets with 100 or $95 \%$ of nutrient requirements achieved, and that in the whole period, the animals which consumed the diets with the enzyme complex had lower excretions and residue coefficients of $\mathrm{Na}, \mathrm{DM}, \mathrm{OM}, \mathrm{Fe}, \mathrm{Cu}$ and $\mathrm{Mn}$. In addition, in the same period, the inclusion of the enzyme complex in diet 95 reduced excretions of MM, N and Ca compared with the animals which consumed the 95 diet, and numerically improved biogas and methane production in the biodigestion of feces. All these findings demonstrate that the use of an enzyme complex in diets with a $5 \%$ reduction in energy and nutrient contents is effective in maintaining growth performance and reducing excretions of nutrients in feces, which represents an interesting strategy for sustainable pig production.

\section{Conclusions}

The majority of the results found in this research demonstrated that the use of an enzyme complex in a diet formulated to provide $95 \%$ of gilts' nutrient requirements reduced fecal excretion and positively affected the anaerobic digestion of feces. These data show that pig nutrition and feeding are important tools for reducing the potential environmental impact of pig production.

\section{Acknowledgments}

Urbano dos Santos Ruiz acknowledges the "Brazilian National Council for Scientific and Technological Development" (CNPq) for his scholarship. 


\section{References}

Aarnink, A.J.A.; Verstegen, M.W.A. 2007. Nutrition, key factor to reduce environmental load from pig production. Livestock Science 109: 194-203.

Adeola, O.; Cowieson, A.J. 2011. Opportunities and challenges in using exogenous enzymes to improve nonruminant animal production. Journal of Animal Science 89: 3189-3218.

American Public Health Association [APHA]. 2005. Standard Methods for the Examination of Water and Wastewater. 21ed. APHA, Washington, DC, USA.

Amorim, A.C.; Lucas, J.; Resende, K.T. 2004. Anaerobic digestion of caprine manure in different seasons. Engenharia Agrícola 24: 16-24 (in Portuguese, with abstract in English).

Association of Official Analytical Chemists - International [AOAC]. 2006. Official Methods of Analysis. 18ed. AOAC, Gaithersburg, MD, USA.

Choct, M. 2006. Enzymes for the feed industry: past, present and future. World's Poultry Science Journal 62: 5-16.

Dourmad, J.; Jondreville, C. 2007. Impact of nutrition on nitrogen, phosphorous, $\mathrm{Cu}$ and $\mathrm{Zn}$ in pig manure, and on emissions of ammonia and odours. Livestock Science 112: 192-198.

Ferket, P.R.; van Heugten, E.; van Kempen, T.A.T.G.; Angel, R. 2002. Nutritional strategies to reduce environmental emissions from nonruminants. Journal of Animal Science 80: 168-182.

Htoo, J.K.; Sauer, W.C.; Yáñez, J.L.; Cervantes, M.; Zhang, Y.; Helm, J.H.; Zijlstra, R.T. 2007. Effect of low-phytate barley or phytase supplementation to a barley-soybean meal diet on phosphorus retention and excretion by grower pigs. Journal of Animal Science 85: 2941-2948.

Marais, J.P. 2000. Use of markers. p. 255-257. In: D'Mello, J.P.F., ed. Farm animal nutrition and metabolism. CAB International, Wallingford, UK.
Miranda, A.P.; Lucas, J.; Thomaz, M.C.; Pereira, G.T.; Fukayama E.H. 2012. Anaerobic biodigestion of pigs feces in the initial, growing and finishing stages fed with diets formulated with corn or sorghum. Engenharia Agrícola 32: 47-59.

Moeser, A.J.; Kim, I.B.; van Heugten, E.; van Kempen, T.A.T.G. 2002. The nutritional value of degermed, dehulled corn for pigs and its impact on the gastrointestinal tract and nutrient excretion. Journal of Animal Science 80: 2629-2638.

Orrico, A.C.A.; Lucas, J.; Orrico, M.A.P. 2007. Characterization and anaerobic digestion of goat manure. Engenharia Agrícola 27: 639-647 (in Portuguese, with abstract in English).

Orrico, M.A.P.; Orrico, A.C.A.; Lucas, J. 2010. Evaluation of anaerobic biodigestion parameters of swine waste fed with diets based on corn and sorghum. Engenharia Agrícola 30: 600607 (in Portuguese, with abstract in English).

Van Keulen, J.; Young, B.A. 1977. Evaluation of acid-insoluble ash as natural marker in ruminant digestibility studies. Journal of Animal Science 44: 282-287.

Wang, J.F.; Jensen, B.B.; Jorgensen, H.; Li, D.F.; Lindberg, J.E. 2002. Ileal and total tract digestibility, and protein and fat balance in pigs fed rice with addition of potato starch, sugar beet pulp or wheat bran. Animal Feed Science and Technology 102: 125-136.

Zhang, Z.; Nyachoti, C.M.; Arntifield, S.; Guenter, W.; Cenkowski, S. 2003. Effect of micronization of peas and enzyme supplementation on nutrient excretion and manure volume in growing pigs. Canadian Journal of Animal Science 83: 749-754. 